plumbo-solvency is being made with the object of improving largo-scale methods of treatment of water. In the meantime, an apparatus has been evolved which on being introduced into $a$ water circuit enables a quantitativo measure of the lead present in the water to be obtained.

\section{Sewage Purification}

As fundamental knowledge was wanting as to the mechanism of methods of treating sewage, such as the activated sludge process, two groups of workers have been engaged on the chemistry and biology of this problem.

The effect of the air-bubbles, which are an essen. tial part of this process, has been examined by chemical and physico-chemical methods, and tho changes which occur in the nitrogen and carbon compounds found in sewage and servage-sludge have been studied in conjunction with the enzymic nctivity of bacterial colls.

\title{
ROAD DEVELOPMENT IN THE UNITED STATES
}

$\mathrm{M}$ R. E. L. LEEMING, an expert on road construction, has given a description in Roads and Road Construction, of October 2, of a motor journey he made recently across the United States from Washington to San Francisco, along the Lincoln Highway. This road is now practically completed.

The first thing which strikes the oye of a road engineer, or a road user, when 'docking' at Now York, is the sight of the motor traffic speeding along the overhead 'express highway' parallel with the Hudson River and linking the busiest parts of 'downtown' with Riverside Drive, Bronx and other suburbs. For the rapid movement of people, this artery is just as important to the city as the underground railways are. In WVashington, since the economic blizzard of 1929, considerable transformation has taken place. Where streets are wide, many things are possible in the way of accommodating traffic. Thero is room for parking at the side or in the centre, and it is possible to construct an underpass of one road relative to another. Mr. Leeming saw a schemo of this kind in progress; one $d$ is boing carried beneath the other, while th urface of the junction is being arranged as a circle to link the connecting roads.

Tho Lincoln Highway connects tho east coast at Now York, where it passes beneath the Hudson River by the new Isincoln tunnel, with tho Pacific coast near Portland. The road touches Philadelphia, Pittsburgh, Fort Wayne, south of Chicago, Cedar Rapids (Iowa), thence crossing Nebraska, Wyoming, Idaho and Oregon. At Wyoming the road crosses the 'continental divide' at a height of about 7,000 feet. At Salt Lake City lie left the Lincoln Highway (U.S.30) and travelled by U.S.40 to San Francisco. Between Nebraska and Wyoming his average speed was $55 \mathrm{~m} . \mathrm{p.h}$. in his Studebaker car and his longest day's run was 610 miles. With daily mileages of $500-600$, the number of restrictions or hazards are fow. Cyclists and pedestrians aro entirely absent, while horse vehicles are very rare.

Some curious notices were observed: "Danger, slippery, beware crickets" (meaning dead grasshoppers). In some of the villages, signs were noticed, such as, "Stop when pedestrians are on the cross. walk", "No overtaking for 700 feet", and so on. Good work is being done in the States in regard to 'safety first' measures by organizing schoolchildren. Selected children are trained as leaders to act as traffic police for the purpose of conducting schoolchildren across the roads to and from school. They carry signs indicating "Stop", and every motorist oboys them. Besides preventing children from being run down on the road, it teaches them to obsorvo habits of 'safety first'. In Salt Lake City, where wide streets occur, parking is arranged with the aid of a special meter mounted on a pedestal opposite each vehiclo parked on the slant. This meter is operated by placing a nickel (2ld.) for half an hour's parking, two nickels or one dime for an hour, and two dimes for two hours. Within these periods an indicator finger is visible at the top of the meter. The meters are only employed between the hours of 9 a.m. and 6 p.m.

Mr. Leeming's journey back from the Pacific coast to Now York was made by air over a route covering the Boulder Dam, Grand Canyon, Toxas, Kansas City, St. Louis and Pittsburg. 'This trip tækes about 18 hours flying time, but compared with the journey by road, one does not acquire any intimate knowledge of the continent. The author strongly recommends a road journey across from east to west, by one of the arterial routes, U.S.30, U.S.40 or U.S.50. If it is not practical to hire or share a car, the Greyhound, a motor-bus service, is always running. These buses travel over tho wholo of the States, day and night, and one can sleep on them in very comfortable reclining chairs, if timo has to bo saved. Tho cost appears to be much less than that of the rail services. While the latter cost 90 dollars return from New York to San Francisco (without extras), the bus services cost about 65 dollars (about £14) for some 6,000 miles. These buses travel along the highways at about 50-60 m.p.h. and make very good progress.

Some indication of the programme of road develop. ment which is likely to be followed in the future is given in the General Motors Exhibition at the New York World Fair. Before making the tour, on the moving chairs of the panorama depicting the high. ways of America in 1940 gradually changing into the highways of 1960, you are shown a large map of the United States on the ceiling. By an arrangement of the lighting the existing roads are replaced by the new system of modern highroads which will cover the whole continent. Mr. Leeming was informed in Vashington that there is enough road development work progressing in the States to keep them busy for the next two generations. Taking into account the remarkable progress which America has already made in road planning, bridge construction and tho provision of flyover junctions, he has no doubt that the scheme outlined at the Vorld Fair will be brought to fruition within the period contemplated. 